\title{
Throwing out the ballast: growth models and the liberalization of German industrial relations
}

\author{
Lucio Baccaro ${ }^{1, *}$ and Chiara Benassi ${ }^{2}$ \\ ${ }^{1}$ University of Geneva; and ${ }^{2}$ King's College London \\ *Correspondence: Lucio.Baccaro@unige.ch
}

\begin{abstract}
This article proposes a new interpretation of the evolution of German industrial relations focusing on the interaction between macroeconomic dynamics and industrial relations developments and specifically on 'growth models'. It argues that there has been a shift in the German growth model from growth pulled by net exports and consumption simultaneously to almost exclusively export-led growth. In addition, exports of machinery and transportation equipment have become more pricesensitive, implying that wage and price increases now pose a greater threat to growth than in the past. These macroeconomic developments have spurred a set of adjustments in the industrial relations sphere with export-oriented firms seeking cost reductions and liberalizations. Industrial relations changes have in turn contributed to entrench export-led growth by augmenting the systemic importance of the foreign sector and reducing the relevance of domestic demand. The export sector has thrived at the expense of real wage stagnation, particularly (but not exclusively) in labour-intensive service sectors, and pattern bargaining has lost its ability to redistribute across sectors and boost domestic demand. The new German model is much leaner and meaner than in the past. Contrary to recent literature, its erosion and liberalization are not limited to the service periphery but affect the manufacturing core as well.
\end{abstract}

Key words: Germany, industrial relations, institutional change, varieties of capitalism, growth models

JEL classification: P16 political economy, E02 institutions and the macroeconomy, J52 collective bargaining 


\section{Introduction}

This article contributes to the debate on the transformation of the German industrial relations system, and more broadly on institutional change in advanced capitalism, by focusing on the interaction between macroeconomic dynamics, specifically the nature and evolution of 'growth models', and developments in the industrial relations sphere (Baccaro and Pontusson, 2016).

Existing scholarship on the evolution of German industrial relations falls broadly in two camps. Scholars in the Varieties of Capitalism ( $\mathrm{VoC}$ ) school have traditionally highlighted the resilience of German-coordinated institutions (Hall and Soskice, 2001a), while their critics have emphasized the erosion of the same institutions and the fundamental liberalization of the system (Streeck, 2009; Baccaro and Howell, 2011). Recently, the two perspectives have come closer to one another. New literature in the VoC tradition has acknowledged the liberalization trend but has insisted that it only affects the service sector, while the manufacturing sector remains immune from it (Palier and Thelen, 2010; Hassel, 2014). Although both perspectives capture important elements, they are both limited by their exclusive focus on supply-side institutions.

In this article, we situate industrial relations developments within the broad transformation of the German growth model. Borrowing freely from New Kaleckian macroeconomics, we argue that supply-side institutions and macroeconomic developments stand in a relationship of 'co-evolution' to one another. This implies that to truly understand the changes undergone by the German model in the last 20 years, one needs to consider macroeconomic developments as well. Specifically, we contend that the German economy has shifted from a model of growth simultaneously led by net exports and household consumption, to an almost exclusively export-led model. Furthermore, exports seem to have become significantly more price-sensitive than in the past in the broad machinery and transport equipment sector, accounting for almost $50 \%$ of total exports. These trends have spurred meso- and micro-level initiatives by export-oriented firms to reduce costs and regain price competitiveness, leading to withdrawal from sectoral collective bargaining, opening clauses and actual or threatened outsourcing. In turn, the weakening of collective bargaining institutions has led to stagnating wage growth both overall and specifically in the lower half of the wage distribution. These distributional dynamics have weakened the ability of household consumption to act as growth engine, reinforcing the systemic importance of exports and the unbalanced nature of the growth model.

Some of the conclusions we draw from the analysis of the growth model and associated institutional changes are similar to those of recent $\mathrm{VoC}$ scholarship. For example, we too find that there is an emerging dualism between the manufacturing sector and the low-end service sector. However, we identify very different causal mechanisms for the observed changes, since our argument emphasizes the price competitiveness of exports and the associated restructuring initiatives by export-oriented firms as crucial variables. Furthermore, we come to very different conclusions with regard to the stability of the system and its future viability. Our analysis suggests that the 'problem' of the German political economy is not just that it is export-led, but that there is a trade-off between export growth and consumption growth. The price sensitivity of exports means that the economy 'needs' a competitive real exchange rate to grow, and this puts constant pressure on the wage bargaining system to keep wage growth in check, and even to produce slower wage growth than trade 
competitors (controlling for productivity), in order to boost price competitiveness in a single currency regime. So far, core manufacturing workers have largely managed to avoid the resulting wage repression, unlike low-end service sector workers for whom wage growth has been non-existent. But there is some evidence of decoupling between wages and productivity even in the manufacturing sector. Furthermore, the spread of atypical work in manufacturing and the substitutability of permanent and temporary workers lead to further downward pressure on wage and working conditions. In brief, the new German model emerges from our analysis looking much less a stable 'equilibrium' than in old and new VoC analyses.

The remainder of the article is organized as follows. The next section reviews the literature on the transformation of the German model. Next, the notion of growth models is introduced, and descriptive evidence is provided to make the point that a shift has occurred in Germany. The fourth section performs an econometric analysis of the price sensitivity of German exports. The fifth section contains an historical reconstruction of the processes by which the industrial relations actors responded to the need to cut costs and gain flexibility, both at the enterprise and at the national level. The sixth section discusses the basic features of the new German model and whether there is any evidence of the emergence of a new political economic 'equilibrium'. The concluding section pulls the various threads together.

\section{Theoretical perspectives on the German model: 'liberalizers' versus 'coordinationists'}

Germany is an important case for the comparative political economy and industrial relations literatures. As the prototypical coordinated market economy (CME), it is, or perhaps one should say that it was, living proof that a more 'worker-friendly' alternative to liberal capitalism not only exists but is even economically successful. In a seminal article, Wolfgang Streeck linked the peculiar features of the German system to a particular production regime, which he called 'Diversified Quality Production' (DQP) (Streeck, 1991).

Streeck's argument was that the high costs generated by industry-level collective bargaining and other institutional rigidities made it very difficult for German firms to compete on wage costs, and forced them to reorient their production strategies towards market niches where quality and customization were crucial for manufacturing success. Simultaneously, the vocational training system ensured an adequate supply, and even an overabundance of skilled workers, which could thus easily adapt to new technologies and innovative work practices (Streeck, 1991). In turn, high employment protection created incentives for both employers and employees to invest in specific skills, while encompassing sectoral agreements and cohesive employer organizations limited the risk of low-wage competition and of skill poaching (Estevez-Abe et al., 2001). Finally, plant-level codetermination fostered labourmanagement cooperation at workplace level (Müller-Jentsch, 1995).

The DQP model was conceived to be the outcome of a set of institutional constraints to which firms had progressively and sometimes reluctantly adapted (Streeck, 1997a). It had developed piecemeal, often as the result of unintended consequences and of favourable environmental circumstances, and in Streeck's original argument it could be easily undone if the latter changed (Streeck, 2009). In particular, if international markets became more pricecompetitive, or if the emergence of a domestic low-wage sector reduced the incentives for firms to invest in skills and innovation, the DQP system could, it was argued, easily lose its lustre (Streeck, 1997a). 
It is unclear that to what extent the stylized 'German model' laid out above has really ever existed, but it is now commonly accepted that it has undergone a great deal of change in the past 20 years (e.g. Hassel and Streeck, 2004; Streeck and Thelen, 2005; Doellgast, 2009). However, the extent and significance of change and the mechanisms driving it are still subject to heated debate. In what follows, we distinguish between two schools of thought, which we call 'coordinationists' and 'liberalizers'. Some authors sit uneasily in either camp (e.g. Herrigel, 2015), but this bipartition helps us to summarize the debate.

\subsection{The coordinationists}

The coordinationist position is held by scholars linked to the Varieties of Capitalism (VoC) school. This school readily accepted the DQP argument summarized above, but sought to embed it within a more rationalist framework and to provide it with micro-foundations (Hall and Soskice, 2001b). Thus, the German-coordinated model was conceptualized as an institutional equilibrium, i.e. as the outcome of the rational strategies of key actors, particularly export-oriented firms.

In David Soskice's seminal analysis (Soskice, 1999), the German model was supported by the pre-strategic preferences of German employers. According to the argument, German employers were aware that their competitive advantage hinged on coordinated institutions and thus were willing to shore up the system independently of the unions' countervailing power (Soskice, 1999, p. 134). This gave the German model a remarkable degree of stability even under conditions of increased economic integration, and set it on a radically different path from economies such as Britain or the USA, which were expected to liberalize due to the absence of firms' capacities for strategic coordination.

While also writing from a VoC perspective, Thelen (2001) always had a more political view of the German model. For example, she saw the preferences of German employers as strategic rather than pre-strategic, and argued that the resulting institutional equilibrium depended on the balance of power between social actors as well. In other words, employers would presumably withdraw their support for non-market coordination if labour lost its ability to pose a credible threat (Thelen, 2001, p. 101). However, Thelen (2001) considered a loss of union power an unlikely event since she saw globalization as strengthening the power resources of labour at least in the German DQP regime, where manufacturing performance depended on close coordination of production stages (Thelen and van Wijnbergen, 2003).

Subsequent analyses have emphasized that, beyond the surface of stability, German capitalism is internally contested (Streeck and Thelen, 2005). Recently, new scholarship in the coordinationist camp has acknowledged the existence and even transformational nature of incremental institutional change, but continues to insist that the core of the German economy remains fundamentally coordinated (Hall, 2007; Carlin and Soskice, 2009; Palier and Thelen, 2010; Hassel, 2014; Thelen, 2014).

According to this new argument, Germany has not experienced a dismantling but rather a shrinking of coordination. This has generated a dual equilibrium with less egalitarian outcomes than in the past, but, at least in so far as the manufacturing sector is concerned, any notion of liberalization is fundamentally misplaced (Palier and Thelen, 2010; Hassel, 2014; Thelen, 2014). 


\subsection{The liberalizers}

The liberalizer camp has often set up its arguments in opposition to coordinationist ones. In contrast to coordinationists, liberalizers hold that German labour market and industrial relations institutions have undergone a wide-ranging process of liberalization, which they see as common to all advanced countries (Streeck, 2009; Baccaro and Howell, 2011; Höpner et al., 2011).

Unions and collective bargaining institutions have become less encompassing (Bosch et al., 2007, pp. 330-334). Far from shoring up coordinated institutions, employers are seen as actively undermining them (Kinderman, 2005; Raess, 2006). Because of companies' shareholder value orientation, it is argued that co-determination has been reengineered to serve the firms' short-term objectives rather than to boost industrial democracy at the workplace (Höpner and Jackson, 2002, p. 364). Instead of decommodifying labour, collective agreements are now used for bringing wage competition within the company's workforce (Holst, 2014). Wage dispersion has widened and the number of low-paid jobs has increased dramatically (Bosch and Weinkopf, 2008).

According to this literature liberalization is by no means limited to low-end services but is on the contrary much more encompassing. The manufacturing sector, it is argued, has experienced growing price-based competition and thinning profit margins (Silvia and Schroeder, 2007; Greer, 2008). The reasons are seen to reside in the new conditions of international competition in export markets. The product quality of German competitors has progressively improved thanks to technological progress and organizational learning (Herrigel et al., 2013). Thus the high-end markets of DPQ memory have become more contestable and this has forced German companies to engage in a constant process of restructuring, which innovates and upgrades while simultaneously cutting costs (Herrigel, 2015).

As labour market regulation weakens and unions' ability to enforce it declines, employers can more easily avoid collective bargaining institutions and employment protection. They use the threat of relocation to increase the willingness of works councils to engage in concessions (Jürgens and Krzywdzinski, 2006), and increasingly rely on staff agencies and subcontractors (Doellgast and Greer, 2007; Helfen, 2011). The use of subcontractors is particularly widespread in Germany because it strengthens the firms' ability to react flexibly and rapidly to changes in demand. At the same time, it allows for cost savings because subcontracting firms are generally not covered by sectoral agreements (Herrigel, 2015).

Despite their different emphases, the coordinationist and liberalizer camps have moved closer to one another in recent years. For example, in Thelen (2014)'s important reformulation of the VoC argument, the puzzle to explain is no longer 'varieties of capitalism' but 'varieties of liberalization'. Thelen's new argument acknowledges that the German economy is undergoing liberalization but explains it as deriving from a 'natural' process of deindustrialization, not from firms' strategic decision to disengage from coordinated capitalism. The German economy is seen as being composed of two sectors characterized by fundamentally different production logics: the manufacturing and the service sector. Coordinated institutions matter for the competitiveness of the former, while the latter relies on market-based coordination. Thus, as manufacturing shrinks and the service sector expands, the economy as a whole becomes more liberal.

Common to both types of arguments is an exclusive focus on the trajectory of supplyside institutions (e.g. sectoral bargaining, vocational training, etc.) and a generalized neglect 
of macroeconomic developments. ${ }^{1}$ Such neglect is unfortunate because, as we argue, changes in Germany's growth model and industrial relations developments 'co-evolve' and it is difficult to fully understand the latter without grasping the former. In the next section, we contend that the German growth model has shifted. Household consumption, which was the most important driver of growth until the 1990s, has lost importance and exports have dramatically increased their systemic relevance.

\section{A shifting growth model?}

The notion of growth model developed in this article is inspired by Neo-Kaleckian macroeconomics. While space restrictions only allow for a cursory overview (see Baccaro and Pontusson, 2016 for a more extensive treatment), suffice it to say that in Neo-Kaleckian macroeconomics output and employment are primarily determined by aggregate demand as opposed to supply-side conditions, and aggregate demand is, in turn, a function of distribution (Bhaduri and Marglin, 1990; Onaran and Galanis, 2012; Storm and Naastepad, 2012; Stockhammer, 2015). This last element is very important for the argument of this article because it establishes a relationship between the social forces and the institutions shaping distributive outcomes and macroeconomic dynamics.

A key tenet of Neo-Kaleckian macro is that due to different propensities to consume and save, distributive shifts favouring wages over profits will have an impact on growth. All other things being equal an increase in real wages controlling for productivity, which is tantamount to an increase in the wage share and a decrease in the profit share, should stimulate consumption. ${ }^{2}$ However, the total impact also depends on the effect on investments and net export. ${ }^{3}$ Although the analysis is generally conducted in terms of shifts in factor shares (wages and profits), it stands to reason that shifts within the distribution of wage income, for example, redistribution from super-managers to low-wage workers, would have similar effects to a redistribution from profits to wages.

The impact of a unit increase in the wage share on investment is theoretically indeterminate: on the one hand, investments tend to be sensitive to profitability rates, and thus should be depressed by distributive changes favouring wages (controlling for productivity); on the other, they are positively related to aggregate demand and are likely to be stimulated if consumption increases. The total impact depends on which of the two effects (profitability vs. demand) prevails. The impact on net exports is instead more clearly negative. Higher wages controlling for productivity should increase imports and reduce exports by leading to an appreciation of the real exchange rate, i.e. by increasing domestic prices more than international prices (assuming plausibly that the nominal exchange rate does not immediately adjust in the opposite direction to counterbalance the shift). Ultimately, an increase in the

1 One exception is Carlin and Soskice (2009), which focuses on the German unemployment crisis of the early 2000s and explains it as resulting from weak aggregate demand. By emphasizing that a restrictive macroeconomic 'demand regime' is functional for export competitiveness and that saving propensities have increased in Germany as a result of macroeconomic uncertainty, their argument has some elements in common with the one we develop in this article.

2 For recent empirical evidence suggesting that consumption out of profit income is significantly lower than consumption out of wage income, see Hartwig (2014, pp. 425-426).

3 Note that the discussion treats government expenditures as exogenous. 


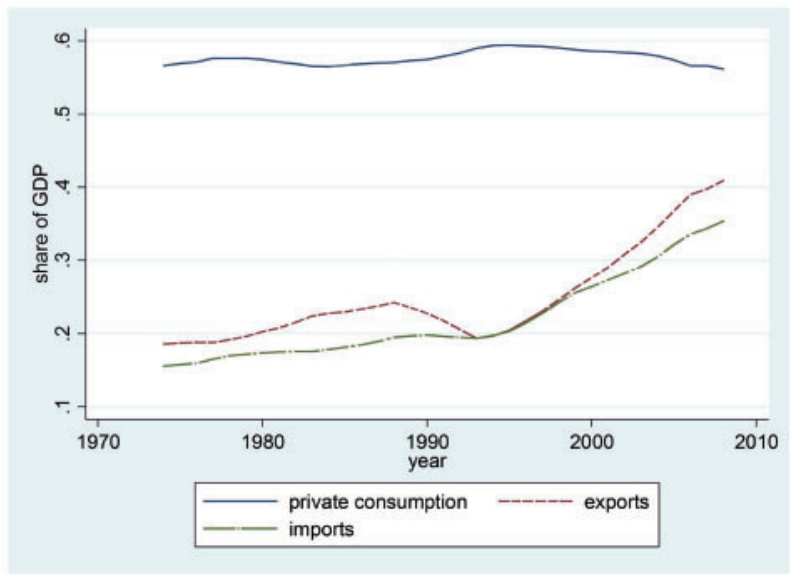

Figure 1. Private consumption, exports and imports as percentage of GDP (constant prices).

Notes: Data are symmetric 5-year moving averages (i.e. 1980 is the average of 1978 through 1982).

wage share will stimulate growth if the consumption effect and the demand effect on investment are stronger than the negative profitability effect on investment and the negative impact on net exports.

Neo-Kaleckian macroeconomists generally distinguish between two types of growth models: wage-led and profit-led depending on the total impact of a unit increase in the wage share. Here we take a similar but more limited focus and examine the role of consumption and exports as drivers of growth. Consumption-led growth may be fuelled by real wage growth but also by growing household indebtedness. In Germany, however, household debt is lower than elsewhere in Europe and has been declining over time (Baccaro and Pontusson, 2016). Export-led growth is a particular type of profit-led growth which emerges when two conditions hold: the export sector is sufficiently large and relative price differences are an important determinant of net exports (Baccaro and Pontusson, 2016).

The requirements for export-led growth may conflict with consumption-led growth and vice versa. If an increase in consumption causes an increase in domestic prices above trade competitors, the expansionary impact of a consumption increase may be partially or even totally offset by the depressing effect on net exports, especially if exports are a large component of aggregate demand and if foreign demand for exports is price-sensitive (Bhaduri and Marglin, 1990; Bowles and Boyer, 1995). Similarly, if wage cuts boost price competitiveness, net exports are stimulated but consumption is repressed. The total impact on growth depends on the size of the respective effects. A country's growth may in principle be pulled both by consumption and exports if exports are relatively price inelastic (Baccaro and Pontusson, 2016).

The importance of exports and consumption as drivers of growth depends on their shares of GDP. As shown in Figure 1, the share of exports in German GDP has been growing dramatically from the early 1990 s on from less than $20 \%$ in volume terms to more than $40 \%$ in 2008 , while the household share of GDP, after spiking in the early 1990 s as a consequence of German unification, has been declining afterwards from $59 \%$ to $56 \%$. The same figure 


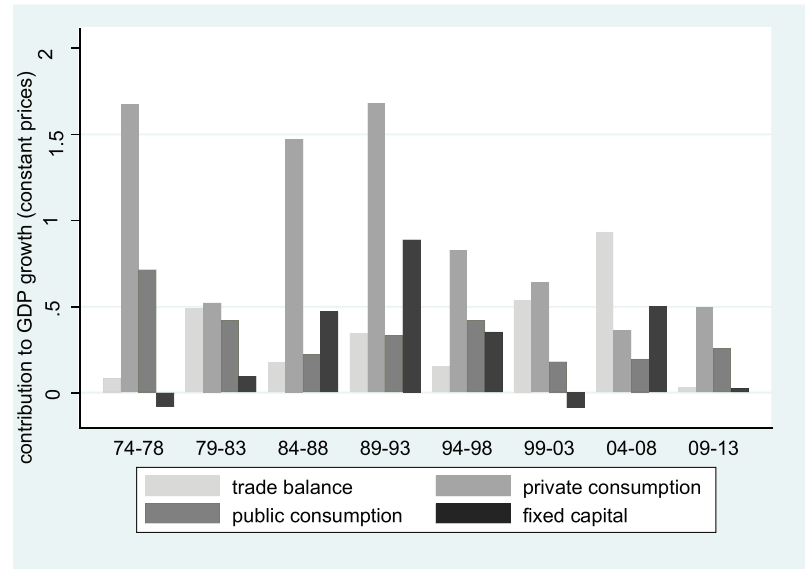

Figure 2. Contribution of demand components (private consumption, investment, government consumption, net exports) to GDP growth: 1974-2013 (5-year averages).

Source: AMECO.

shows that imports have also increased as a percentage of GDP but less than exports thus leading to a growing trade balance surplus.

Figure 2 reports a simple growth decomposition exercise by calculating the annual growth rate of major components of aggregate demand (household consumption, investment, government consumption and net exports) weighing each by their share of GDP. This allows us to assess the relative importance of each demand component as a driver of growth. Data are organized in 5-year averages. The growth contribution of private consumption largely exceeded that of any other component until the early 1990, with the exception of the recession of the early 1980s. Public consumption also played a non-negligible role in 19741979. From 1994 on, however, the contribution of consumption declined constantly and became a negligible $0.4 \%$ in 2004-2008, while the contribution of net exports increased constantly and reached 0.9 in the same period. The main drivers of German growth seem to have changed over time, and although it is difficult to pinpoint a clear date, the shift may have taken place in the early 1990s. Also, a trade-off seems to have emerged between net exports and domestic consumption. In 2009, there was a dramatic collapse of international trade and the German economy rebalanced a bit: the growth contribution of net exports declined and the growth contribution of consumption increased a little. However, the adjustment was not large enough to undo the previous trends and the trade balance became strongly positive again in more recent years.

One possible explanation for the trade-off between exports and consumption is that exports have become more price-sensitive over time. If exports are price-sensitive, expanding exports requires repression of wages and consumption to prevent an appreciation of the real effective exchange rate (REER). The next section explores the plausibility of this hypothesis. 


\section{The price-elasticity of German exports}

The claim that German exports may have become sensitive to price differences runs counter to much received wisdom in comparative political economy. According to both the Streeck (1991, 1997a) and Hall and Soskice (2001b) arguments referred above, German firms do not compete on costs; rather, thanks to the 'enabling constraints' of the rigid institutional ecosystem in which they operate, they compete on quality. The implicit assumption of this literature is that German exports are not very price-sensitive. To our knowledge, this hypothesis has never been tested in political economic research. However, it has been tested in trade economics and the econometric evidence does not support it. In fact, Stahn (2006) summarizes the findings of studies covering the 1970s and 1980s as follows: 'Most studies find that price competitiveness has a noticeable influence on exports, with a coefficient having an absolute value of just below 1.0'. A coefficient of 1 means that an increase of $1 \%$ in domestic prices relative to foreign prices (expressed in domestic currency) reduces export growth by $1 \%$. Breuer and Klose $(2014$, p. 9) have recently estimated export equations for a number of European countries for 1995-2012. They have found that German exports have a price elasticity of 0.82, which is smaller than France's but greater than Austria, Belgium, the Netherlands and other countries. The European Commission (2014) has found a price elasticity of German export of 0.81 for 1994-2014, slightly higher than the average for the Euro area as a whole (0.77). Thus, German exports do not seem particularly priceinsensitive in comparative perspective.

The recent literature on the price-elasticity of German exports (whose results are summarized in Appendix A) has the following common features: (a) the basic specification is growth of export volumes regressed on foreign demand and relative price differences; (b) the model is estimated in first differences if no evidence of cointegration is found or with some variant of the error correction model (ECM) otherwise; (c) results tend to vary considerably depending on the indicator of price competitiveness used (Bayoumi et al., 2011) and the time period selected. With regard to the post-unification period, studies whose coverage ends in the early 2000s tend to find smaller or even insignificant elasticities (Stahn, 2006; Danninger and Joutz, 2008), while studies reaching the early 2010s find greater elasticities suggesting the possibility of growing effects over time (Thorbecke and Kato, 2012; Breuer and Klose, 2014; European Commission, 2014).

Against this background, a recent study by Storm and Naastepad (2015) is interesting because it embraces the classic VoC argument about the sources of German export success and seeks to provide empirical support for it (see also Storm and Naastepad, 2012). Storm and Naastepad argue forcefully that the recent German export success has nothing to do with any wage or cost compression and everything to do with Germany's superior non-price competitiveness, which in turn is determined by the 'distinctly non-neoliberal dimensions of Germany's economic model' (Storm and Naastepad, 2015, p. 12). They do not focus on the real exchange rate, but on unit labour costs (ULCs) relative to the main trade partners (RULC), and find an insignificant coefficient of RULC using quarterly data for 2006-2014. A crucial assumption of this analysis is that the contribution of manufacturing ULCs to export prices is strictly in proportion to the share of ULCs in total manufacturing costs $(25 \%)$. Based on this assumption, Storm and Naastepad (2015, p. 14) divide existing estimates of the impact of relative prices by four. However, ULCs in manufacturing may contribute to export price formation both directly and indirectly, i.e. by influencing other prices, 
such as the price of service inputs. This seems especially likely to happen in a coordinated wage bargaining system such as Germany's. Storm and Naastepad (2015, ft. 3, p. 14) seem aware of this problem and in fact they argue: 'When dismissing RULC [relative ULCs] as a factor determining competitiveness and current account imbalance, we are not implying that the same holds true for the (real) exchange rate'. Thorbecke and Kato (2012) come to the opposite conclusion to Storm and Naastepad (2015) and argue that Germany's large internal devaluation is responsible for the recent export surge. Their econometric analysis finds that German exports to the Euro area are more price-sensitive than exports outside the Eurozone, but also (in partial support of Storm and Naastepad's findings) that real exchange rates based on relative ULCs have lower elasticities than real exchange rates based on consumer prices (0.6 vs. 1$)$.

Overall, it is not possible to come to any definite conclusion about the price sensitivity of German exports and whether it has changed over time solely based on the literature. While there is consensus that German exports respond negatively to real exchange rate appreciation, the estimated magnitudes vary and it is not clear whether price sensitivity has increased or decreased in more recent years. Thus, in the remainder of the section we perform our own analysis. Before proceeding further, however, it is important to state clearly that the argument about the growingly export-led nature of the German growth model does not hinge solely on exports having become more price-sensitive. Elasticities need to be evaluated at a particular point of the distribution of independent variables and so the size of the export sector matters (Bhaduri and Marglin, 1990; Bowles and Boyer, 1995). Since the German export sector has expanded dramatically in the past 25 years, even with unchanged price elasticities wage restraint (which is recessionary for a wage-led economy) should have a progressively more expansionary effect on total demand through the stimulation of net exports, and the stimulation of net exports should at some point counterbalance the contraction of consumption demand.

In performing our analysis, we draw from and extend the work of Stockhammer et al. (2011). They provide a detailed econometric assessment of the impact of globalization on the German growth model. Using annual data for 1970-2005, Stockhammer and coauthors find that the coefficient of the relative price variable almost doubled between 19701987 and 1987-2005. However, perhaps because of the small number of observations, the difference was not statistically significant.

As it customary, we model manufacturing export volumes as a linear function of foreign demand and price competitiveness. Data on exports are from the AMECO database. ${ }^{4}$ We also use data from the UN COMTRADE database on the largest export sector in Germany: machinery and transport equipment. ${ }^{5}$ Foreign demand is operationalized with world real GDP (excluding Germany) from the World Development Indicators database (for a similar choice, see Onaran and Galanis, 2014). ${ }^{6}$ Price competitiveness is measured in two ways: as the ratio between export prices and import prices, both from the AMECO database (Px/Pm; as in Stockhammer et al., 2011; Onaran and Galanis, 2014), and as REERs based on ULCs

4 http://ec.europa.eu/economy_finance/db_indicators/ameco/index_en.htm, accessed on January 10, 2016.

5 http://wits.worldbank.org/default.aspx, accessed on October 23, 2014.

6 http://data.worldbank.org/data-catalog/world-development-indicators, accessed March 1, 2016. 
in manufacturing from the Fred Database $(R E E R / U L C) .{ }^{7}$ All series are non-stationary in levels and integrated of order 1, i.e. stationary in first differences. We find no evidence of cointegration among our variables. Thus, we estimate the models in first differences (as in Stockhammer et al., 2011; Onaran and Galanis, 2012; Storm and Naastepad, 2015). Logging the variables allows us to interpret the coefficients as elasticities (percentage change). For reasons of space, we report here the key steps of the analysis. Details are consigned to the footnotes. ${ }^{8}$

Table 1 columns 1 and 2 present two regression models for total exports of goods in 1971-2014 distinguishing between the two measures of price competitiveness: $\mathrm{Px} / \mathrm{Pm}$ or REER/ULC. The coefficients for relative price growth are always negative and significant and in the same ball park as previous estimates. The elasticity is higher when relative price growth is measured with export prices relative to import prices than with REERs based on manufacturing ULCs. An increase of price competitiveness of $1 \%$ is associated with a decline of export growth of 0.8 for $\mathrm{Px} / \mathrm{Pm}$ and of $0.4 \%$ for REER/ULC. The models also suggest that each $1 \%$ increase of world GDP growth is associated with an increase of German export growth of about $3 \%$ on average. ${ }^{9}$

Table 1 columns 3-6 test whether there has been a shift in the price-sensitivity of German exports in the post- 1990 period by interacting the price variable with a post-1990 dummy. Models three and four focus on total manufacturing exports distinguishing between the Px/Pm and REER/ULC measures of relative prices, respectively. Models five and six focus on the machinery and transport equipment sector distinguishing again between $\mathrm{Px} / \mathrm{Pm}$ and REER/ULC, respectively. With $46 \%$ of total exports of goods on average, this sector (which includes both the auto industry and the machine tool industry) is the largest export sector in Germany. There is a significant increase in the price elasticity of exports in the machinery and transportation equipment sector in the period post-1990: the coefficient of the interaction term is four times larger than the main effect, which is instead insignificant. The estimates suggest that a $1 \%$ increase in the ratio of export to import prices was not associated with a significant decrease of exports in the 1970s and 1980s, but in the 1990, 2000s and early 2010 s it was associated with a decline of $1.3 \%$ on average. In the other models, the interaction term is negatively signed but not significantly different from zero, which suggests that the increase in price elasticity is not a general feature of the manufacturing sector but only of its largest component. ${ }^{10}$ Even within the machinery and transportation sector, the effect is significant only when the $\mathrm{Px} / \mathrm{Pm}$ measure of relative prices is used but not when

7 https://research.stlouisfed.org/fred2/, accessed September16, 2015.

8 For stationarity, we perform the Augmented Dickey-Fuller test with various combinations of trend, constant and lag order. For cointegration, we run both an Engle-Granger cointegration test and a Johansen cointegration test (trace test and maximum eigenvalue test). These tests are available upon request.

9 The negative intercepts indicate a negative time trend controlling for other determinants. This is probably a result of the entry of new competitors over time. The autocorrelation tests at the bottom of the table suggest that first-order serial correlation is not an issue.

10 We also estimated regressions for the other largest sectors: exports of chemical and related products (representing on average $14 \%$ of total exports of goods), manufactured goods classified chiefly by material (e.g. leather, textile, etc.; $17 \%$ ) and miscellaneous manufactured articles $(10 \%)$. In these regressions, the main effect was negative and significant with the $\mathrm{Px} / \mathrm{Pm}$ indicator of relative prices, and there was no evidence of a significant coefficient change in the post-1990 period. There seems to be sectoral heterogeneity in the price sensitivity of exports, which should be explored in future research. 
Table 1. Determinants of manufacturing export growth (volume) with period-specific price elasticities

\begin{tabular}{|c|c|c|c|c|c|c|}
\hline & (1) & (2) & (3) & (4) & (5) & (6) \\
\hline Sector & Total & Total & Total & Total & $\begin{array}{l}\text { Machines } \\
\text { and Transp }\end{array}$ & $\begin{array}{l}\text { Machines } \\
\text { and Transp }\end{array}$ \\
\hline $\begin{array}{l}\text { Relative price } \\
\text { indicator }\end{array}$ & $\mathrm{Px} / \mathrm{Pm}$ & REER/ULC & $\mathrm{Px} / \mathrm{Pm}$ & REER/ULC & $\mathrm{Px} / \mathrm{Pm}$ & REER/ULC \\
\hline World GDP growth & $\begin{array}{l}2.796 * * * \\
(0.404)\end{array}$ & $\begin{array}{l}3.075^{* * *} \\
(0.451)\end{array}$ & $\begin{array}{l}2.859 * * * \\
(0.450)\end{array}$ & $\begin{array}{l}3.105^{* * *} \\
(0.528)\end{array}$ & $\begin{array}{l}2.357^{* * * *} \\
(0.630)\end{array}$ & $\begin{array}{l}2.677^{* * *} \\
(0.631)\end{array}$ \\
\hline Relative price growth & $\begin{array}{l}-0.855^{* * *} \\
(0.188)\end{array}$ & $\begin{array}{l}-0.402^{* * *} \\
(0.148)\end{array}$ & $\begin{array}{l}-0.800^{* * *} \\
(0.212)\end{array}$ & $\begin{array}{c}-0.327 \\
(0.212)\end{array}$ & $\begin{array}{l}-0.310 \\
(0.299)\end{array}$ & $\begin{array}{c}-0.368 \\
(0.258)\end{array}$ \\
\hline \multirow[t]{2}{*}{$\begin{array}{l}\text { Relative price } \times \\
\text { Post-1990 }\end{array}$} & & & -0.256 & -0.137 & $-1.392 * *$ & -0.471 \\
\hline & & & $(0.471)$ & $(0.337)$ & $(0.662)$ & $(0.408)$ \\
\hline Post-1990 & & & $\begin{array}{c}1.616 \\
(1.197)\end{array}$ & $\begin{array}{c}1.238 \\
(1.402)\end{array}$ & $\begin{array}{c}1.460 \\
(1.702)\end{array}$ & $\begin{array}{c}0.842 \\
(1.718)\end{array}$ \\
\hline Constant & $\begin{array}{l}-3.782^{* * * *} \\
(1.366)\end{array}$ & $\begin{array}{l}-4.785^{* * *} \\
(1.527)\end{array}$ & $\begin{array}{l}-4.839^{* * *} \\
(1.785)\end{array}$ & $\begin{array}{l}-5.580^{* * *} \\
(2.072)\end{array}$ & $\begin{array}{c}-3.107 \\
(2.493)\end{array}$ & $\begin{array}{c}-4.161 \\
(2.489)\end{array}$ \\
\hline Observations & 44 & 44 & 44 & 44 & 42 & 42 \\
\hline r2_a & 0.645 & 0.547 & 0.647 & 0.537 & 0.452 & 0.471 \\
\hline $\begin{array}{l}\text { Durbin autocorrelation } \\
\text { test }\end{array}$ & n.s. & n.s. & n.s. & n.s. & n.s. & n.s. \\
\hline
\end{tabular}

the real exchange rate based on ULCs is used. This suggests that relative ULCs are a weaker determinant of export success than export prices as a whole. ${ }^{11}$

To explore the evolution of price elasticity further, Figure 3 displays the results of moving-window regressions for the machinery and transportation equipment sector. The graphs are based on the model in Table 1, which is estimated for shifting 11-year intervals beginning with 1972-1982 and ending with 2003-2013. Relative price coefficients and $90 \%$ confidence interval are plotted over time. The graph on the left reports the estimates obtained when using the Px/Pm indicator; the one on the right the REER/ULC one. Given the small number of observations the confidence intervals are large and often cover zero. However, there is a clear negative trend in both graphs. The price elasticity of exports seems to have increased more dramatically when using export prices relative to import prices, but also with real exchange rates based on relative ULCs. ${ }^{12}$

Overall, the analysis suggests the following: (a) German exports are price-sensitive-over the 1971-2014 period a loss of price competitiveness of $1 \%$ is associated with a decrease of exports of $0.8 \%$ for the manufacturing sector as a whole; (b) exports respond more to

11 The positive sign of the period dummy suggests that export growth is greater in the post-1990 period, although the dummy is never significant.

12 The models after 1997 include a dummy for 2008. The year 2008, the first year of the global crisis, is characterized by a decline of export growth in machinery and transportation equipment not adequately captured by a decline in world growth and with an increase in price competitiveness. It is therefore an outlier. Qualitative findings are similar if regressions are estimated without the dummy. 

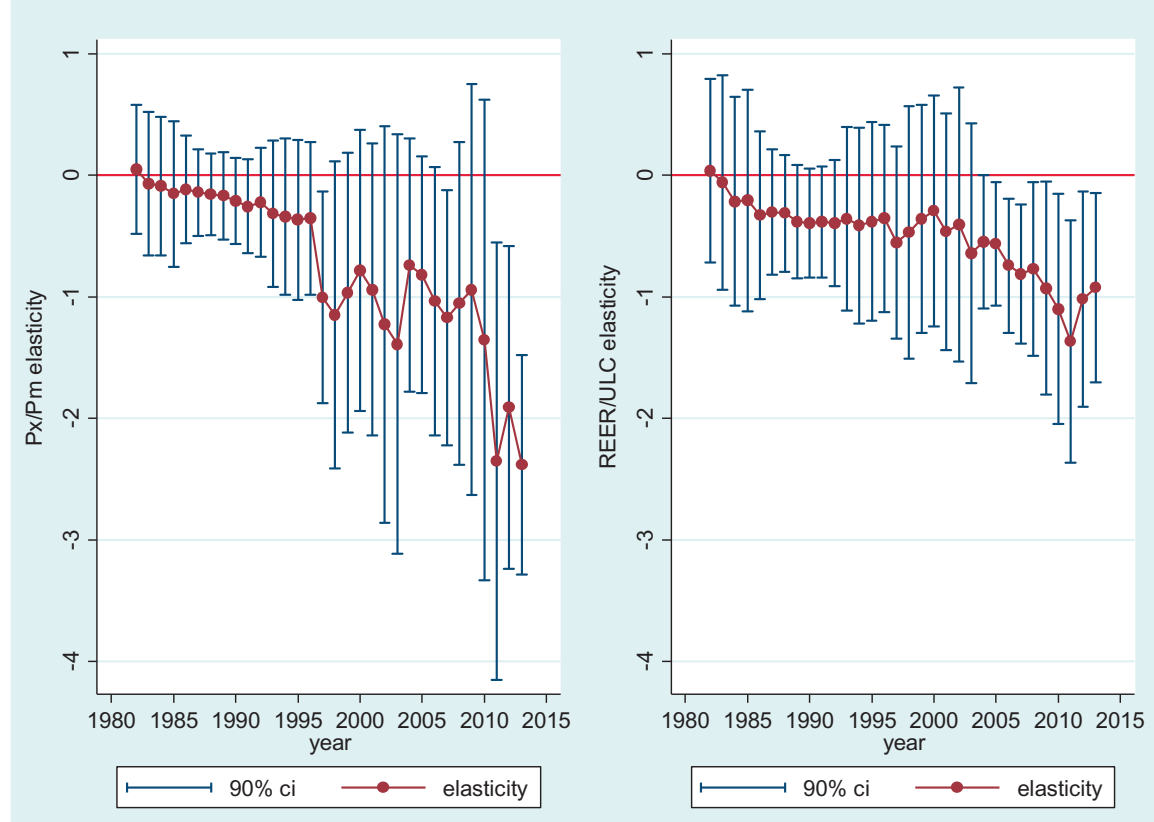

Figure 3. Price elasticity of exports from moving-window regressions: machinery and transportation equipment.

Notes: The graphs are based on the model in Table 2 and plot coefficients and confidence intervals for 11-year moving-window regressions. The years on the $x$-axis correspond to the last year of the interval. For example, 1982 is the coefficient of a regression estimated on data between 1972 and 1982.

movements in overall export prices (which are also affected by profit margins, price of intermediate goods and price of service inputs) than to movements in relative ULCs in manufacturing; (c) there is evidence of an increase in the price elasticity of exports over time in the machinery and transportation equipment sector, but not in manufacturing as a whole. In the machinery and transportation equipment sector, exports were price-insensitive in the 1970s and 1980s (consistent with the DQP and CME arguments) but have become increasingly more price-sensitive in the post-1990 period.

In sum, the analyses in this and the previous section suggest that important changes have occurred in Germany's growth model. Growth used to be pulled primarily by consumption until the early 1990s but became almost exclusively export-driven afterwards. In addition, contrary to much received wisdom in comparative political economy, German exports are sensitive to relative price differences and their price sensitivity seems to have increased in the leading machinery and transportation equipment sector. It needs to be added that the single European currency has probably contributed to cement the German export-led growth model by ruling out compensating nominal exchange rate devaluations by the main European partners. In the next section, we provide an argument for both the cause and the effect of export price sensitivity. In the 1990s, Germany's key export markets (such as the auto industry) became progressively more competitive because international competitors 
found new and cheaper ways to produce high quality products. Faced with tougher competitive conditions, export-oriented firms responded by cutting costs and by relaxing institutional rigidities, and this led to a progressive erosion of industrial relations.

\section{The trajectory of German industrial relations}

Industrial relations are crucial institutions both for the demand side and the supply side of the political economy, and their transformation has played a fundamental role for the changes undergone by the German model. On the one hand, industrial relations redistribute income from capital to labour, and across skill levels and sectors (Machin, 1997; Wallerstein, 1999; Rueda and Pontusson, 2000). Therefore, they play a crucial role in supporting internal demand as wage incomes and middle incomes have a higher propensity to consume than capital incomes and high incomes (Klär and Slacalek, 2006; Stockhammer et al., 2009). On the other hand, industrial relations also determine the cost of labour, affecting the price competitiveness of exports.

In the traditional German model of textbook fame, i.e. approximately between the 1970s and the 1980s (Streeck, 1997a), industry-level bargaining set uniform wage and working conditions not only within but also across sectors. Unions in export-oriented sectors (such as IG Metall) negotiated wage increases in line with economy-wide productivity gains, which are generally lower than sector-specific ones, in order to create a common wage floor for unions in less dynamic sectors; this system of pattern bargaining redistributed income from workers in more productive sectors and companies to workers in less productive ones (Schulten, 2001, p. 5). At company-level, although works councils contributed to render the system more flexible (Thelen, 1991), agreements with the works councils were subordinated to industry-level agreements (Müller-Jentsch, 1995), and thanks to high unionization rates among works councillors (Niedenhoff, 1981, pp. 27-30), unions could prevent the diffusion of a company-oriented logic. Works councils enforced the application of sectoral agreements to all workers in the firm along the once vertically integrated value chain. Thus, in a manufacturing company, workers employed in logistics, catering and cleaning services were covered by the same collective agreement as their colleagues in more 'productive' business units such as the assembly line or forging.

In the 1980s, bargaining coverage was around $80 \%$ (Streeck, 1997b, p. 244) and union density in the metal sector was around 40-45\%, 10 percentage points higher than the overall organization rates (Hassel and Schulten, 1998, p. 499). The employers' association organized firms with over $77 \%$ of the employees (Silvia and Schroeder, 2007, p. 1440). The high coverage was also due to the relatively frequent declarations of collective agreements as 'generally binding'. In Western Germany, between 500 and 600 collective agreements per year were declared generally binding in the period 1977-1987, with a peak of 608 in 1980 (BMAS, 2013, p. 7). In 1984/1985, almost 43\% of generally binding agreements covered wage issues (Data by Wonnenberg cit. in Bispinck, 2012, p. 502).

The first signs of collective bargaining decentralization emerged in the mid-1980s, when IG Metall conceded the introduction of opening clauses about working time flexibility at the workplace in exchange for a 35-hour working week (French, 2000, p. 203). While only the Western metal industry and the printing industry achieved the goal of 35 hours/week in the 1990s (Hassel and Rehder, 2001, p. 14), the working-time offensive of IG Metall paved the 
way for collective bargaining decentralization because it institutionalized workplace negotiations.

The German unification contributed further to this trend even though it was initially decided that traditional bargaining institutions would be transferred in block to Eastern Germany to favour the convergence of wages and welfare levels. In 1991, unions and employers' associations in the metal sector signed a staged wage agreement (Stufenplan) to achieve wage parity by 1994 (French, 2000, p. 204). When the Eastern German economy collapsed, however, Gesamtmetall (the metalworker employer federation), responding to the pressure of small and medium-size enterprises in Eastern Germany, suspended the Stufenplan in 1993 and asked for new negotiations and the introduction of opening clauses at company level. IG Metall was forced to accept opening clauses. These were initially placed under the supervision of a commission of employer and union representatives (French, 2000, pp. 206-208). Still, the agreement implied the progressive institutionalization of exceptions to the rigid sectoral bargaining. These exceptions rapidly spread during the employers' cost offensive of the 1990s.

After unification, unemployment ballooned in Eastern Germany. Demand for local products declined due to competition from 'new' Western products and to price appreciations in the order of $300 \%$ after the introduction of the D-Mark. Furthermore, the competitiveness of Eastern firms was undermined by rapid wage increases while productivity stagnated (Lindlar and Scheremet, 1998). After a short-lived boom, in the early 1990s unemployment started rising in West Germany as well. The burden of unification on the public budget did not allow expanding vocational training or using early retirement schemes to mitigate job losses (Jürgens, 1997, p. 112). High wages were identified as one of the main causes of structural unemployment. It was argued that they impaired the competitiveness of the German production model as the rise of US and Japanese manufacturers brought labour-cost competition into high-quality product markets (Herrigel, 1997, pp.178-179). In addition, high labour costs, especially for low- and middle-skilled workers, prevented employment growth in the most labour-intensive segments of manufacturing (Sinn, 2006) as well as in private services (Scharpf, 1997).

Faced with a cost problem, the German manufacturing industry engaged in intense restructuring since the beginning of the 1990s. Manufacturing companies introduced lean production techniques and restructured their value chain into modules carried out by suppliers (Jürgens, 2004; Greer, 2008). Furthermore, the new markets in Eastern Europe allowed companies to access cheap production sites (Jürgens and Krzywdzinski, 2006). It is true that Kinkel and Maloca (2009) also report cases of backshoring after a few years, mainly from Czech Republic, Poland and Hungary, but outsourcing does not necessarily require to be actually carried out to achieve concessions. If the threat is credible, it alone is sufficient. According to a survey by the Fraunhofer Institute, over $40 \%$ of companies in core manufacturing sectors outsourced part of their production abroad between 1999 and 2001, and $75 \%$ of these companies did so mainly for reducing production costs (Kinkel and Lay, 2003, p. 4). Similarly, a survey by the Cologne Institute for Business Research reports that around $60 \%$ of enterprises between 1000 and 5000 employees set up new plants outside the old EU Member States (cit. in Sinn, 2006, p. 1160). Export companies were particularly active in offshoring and the import content of German exports increased from $25 \%$ at beginning of the 1990 s to $38 \%$ by 2004 (Ludwig and Brautzsch, 2008, p. 177). 
The massive outsourcing of low-skilled manufacturing jobs and the high unemployment rate (around $10-12 \%$ from the 1990s to mid-2000s) provided the background for a heated debate over the future of Germany as production site (Standortdebatte). The Standortdebatte focused on the necessity to cut labour costs in order to re-gain competitiveness and to save jobs, contributing to building a consensus around the imperative of reforming collective bargaining, labour market and welfare institutions (Upchurch, 2000, p. 76). In the first half of the 1990s, the employers' associations—especially Gesamtmetall—started withdrawing from sectoral bargaining institutions. Following Eastern Germany, the pressure for lower wage levels and flexible company-level solutions grew also from Western German small- and middle-sized companies (Hassel and Rehder, 2001, p. 5). Thus, the employers' associations introduced the option of membership without applying the sectoral agreement (OT-Mitgliedschaften), and Gesamtmetall achieved a contested agreement in 1994, which froze wages for 1 year and allowed companies to bargain with works councils over a working time reduction up to 30 hours/week in exchange for employment security (Turner, 1998, pp. 104-106).

Workplace agreements known as Pacts for Employment and Competitiveness (PECs) quickly spread across sectors both in Eastern and Western Germany, especially in companies with an internationalized product strategy. Works councils were made co-responsible for the competitiveness of the production site and were put under great pressure for concessions because of the credible threat of disinvestment or outsourcing and the high unemployment rates. PECs included concessions regarding working time, work reorganization, early retirements and wage cuts or freezes, and could amend the sectoral agreements for the first time (Rehder, 2003). Initially legitimated as a response to an exceptional economic situation (Hassel and Rehder, 2001), since the end of the 1990s, the PECs have become an institutionalized tool for co-management, bringing the decentralization of collective bargaining a step forward (Rehder, 2003, p. 118). While the diffusion of PECs started in the manufacturing sector, it also affected the service sector (Seifert and Massa-Wirth, 2005). In particular, research found that PECs were used in the infrastructure industries that had been privatized at the end of the 1990s to respond to rising market competition (Rehder, 2003; Doellgast, 2009).

The unions started worrying that the spreading of formal opening clauses and of informal agreements among local-level actors would undercut sectoral agreements. To regain a modicum of control over the centrifugal tendencies, especially of large work councils, IG Metall signed the Pforzheim Agreement in 2004. The agreement made derogations to collective agreements possible, but only if employers offered concrete measures for safeguarding jobs, such as new production investments. Also, sectoral unions and employers' associations were to be actively involved in the negotiations (Haipeter, 2009).

Parallel to these developments at company and sectoral level, there were national-level attempts to come up with a negotiated response to high unemployment, but they were unsuccessful. The Alliance for Jobs set up in 1995- a national tripartite bargaining forumfailed because unions refused the package of labour market reforms and welfare cuts proposed by the government and employer association (Bispinck and Schulten, 2000). The Parliament approved some of the measures anyway in September 1996. The duration of temporary employment contracts was extended up to 24 months, and the qualification safeguard clause for the unemployment benefits was lifted, pushing the unemployed to accept work at low qualification levels (Eichhorst and Marx, 2011). Three years later the second 
Alliance for Jobs, Training and Competitiveness also failed to agree on a package of concrete measures to counter unemployment (Bispinck and Schulten, 2000).

Faced with social partner stalemate, the Red-Green government launched a programme of unilateral reform. The 'Commission for Modern Labour Market Services'-or Hartz Commission after the name of his chair Peter Hartz-was in charge of the Agenda 2010, which aimed at decreasing the unemployment rate by $50 \%$ over 3 years (Menz, 2005, p. 204). The Hartz reforms were approved between 2003 and 2005, and had a strong impact both on the welfare system and on the labour market. Hartz I deregulated the use of agency contracts by lifting any obligation to specify the reason for the fixed-term contract and to hire agency workers permanently after a certain period. Furthermore, collective agreements could amend the equal pay principle set by law (Bundesagentur für Arbeit, 2011, p. 5). Hartz II extended the application of lower social security contributions and tax rates to marginal part-time jobs up to $800 € /$ month and lifted the limitation of weekly hours; it also created subsidies for self-employment (Jacobi and Kluve, 2006). Hartz IV merged unemployment benefits and social benefits. The period covered by unemployment benefits was shortened to a maximum of 18 months, and the eligibility criteria for unemployment assistance were tightened. Furthermore, the criteria defining the acceptability of a job were changed in order to increase the pressure on Hartz IV recipients to actively engage in the job search (Hassel and Schiller, 2010, pp. 26-34).

The Hartz reforms encouraged unions and works councils in the manufacturing sector to bargain around wage flexibility and other internal flexibility measures to increase the prospects for job security of core workers (Eichhorst and Marx, 2011). However, they mostly affected the service sector, thus deepening the gap between this sector and the manufacturing sector. Indeed, the service sector has traditionally been less organized than the manufacturing sector in Germany (Dølvik and Waddington, 2002) and had (slightly) lower bargaining coverage rates already in the 1990s, as shown in the following section. Furthermore, atypical work, especially marginal part-time jobs, had already started spreading in the 1990s, as atypical contracts allowed employers to save on social security contributions and on wage costs (Eichhorst and Marx, 2011, p. 21). By further liberalizing the use of atypical contracts, the Hartz reforms contributed to creating a stable low-wage service sector (Palier and Thelen, 2010; Hassel, 2014).

In sum, the German model of industrial relations has undergone considerable political and economic liberalization in the past 20 years, and the manufacturing firms' efforts to cut costs and boost external competitiveness have been at the forefront of the reform process. Liberalization was incremental in manufacturing and more radical in the service sector due to traditionally weaker institutions and to the Hartz reforms. The next section uses new data on bargaining coverage and on differences between insiders and outsiders to illustrate some of the outcomes of the process.

\section{The new German model}

Although the organizational erosion of German class actors has been well documented (Hassel, 1999; Bosch et al., 2007), the extent to which sectoral collective bargaining has been eroded by the liberalizing trends illustrated above, including in core sectors, is less well known. Our analysis relies on data from the Establishment Panel of the Institute for Employment Research (IAB), which is an annual representative employer survey. Table 2 


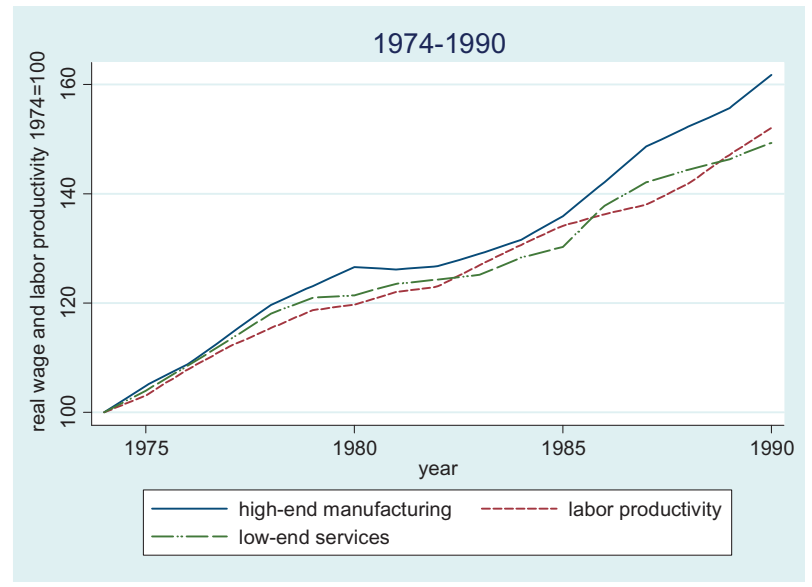

Figure 4. Trends in real wages (high-end manufacturing and low-end services) and labour productivity (total economy) in 1974-1990.

Source: Own elaborations on EU KLEMS data (for the definition of sectors, see text).

reports data on the coverage rates of sectoral and company-level bargaining measured as percentage both of the workforce and of establishments for the manufacturing and the private service sectors. ${ }^{13}$ Sectoral bargaining coverage is declining steeply in both manufacturing and services: the workforce coverage rate was $80.3 \%$ in manufacturing and $71.1 \%$ in services in 1995 and by 2013 it had fallen to $50.4 \%$ in manufacturing and $45.2 \%$ in services. In other words, there has been a loss of 25-30 percentage points in 18 years, and there are no dramatic differences in coverage between manufacturing and services. The decline was not compensated by company-level agreements, whose coverage rates only slightly increased in manufacturing while it halved in services.

Equally if not more worrisome are trends in the sectoral coverage rates of establishments. This coverage rate was $63.2 \%$ in manufacturing and $56.7 \%$ in services in 1995 , and it fell to $26.9 \%$ in manufacturing and $32.4 \%$ in services in 2013 . In other words, now the proportion of establishments covered by sectoral agreements is greater in services than in manufacturing.

Furthermore, between 2005 and 2007 (the 2 years for which data are available), over $20 \%$ of the manufacturing establishments covered by sectoral agreements made use of opening clauses, which, as argued above, can amend the provisions set by collective agreements. Overall, the above evidence suggests that industry-level bargaining is still the main type of bargaining in Germany, but is full of holes, since only about 30\% of German manufacturing establishments is covered by a collective contract of any type.

13 The following manufacturing industries are included: pulp, paper, paper printing and publishing; chemical, rubber, plastics and fuel; other non-metallic mineral; basic metals and fabricated metal; machinery, not elsewhere classified (NEC); electrical and optical equipment; transport equipment; manufacturing NEC; recycling, food processing; textile; services includes retail trade, except of motor vehicles and motorcycles; repair of household goods; hotels and restaurants; and the category 'other personal services'. 


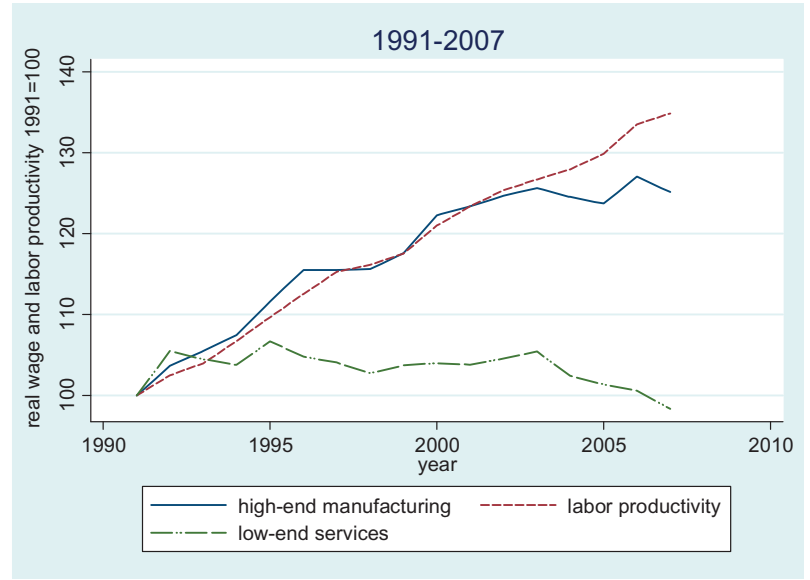

Figure 5. Trends in real wages (high-end manufacturing and low-end services) and labour productivity (total economy) in 1991-2007.

Source: Own elaborations on EU KLEMS data (for the definition of sectors, see text).

The softening of industry-level agreement has important consequences for the ability of collective bargaining institutions to redistribute productivity growth within and across sectors, thus stimulating domestic demand and consumption. This function was key for supporting wage incomes in low-end services, but the redistributive function of the traditional pattern bargaining system seems to have eroded. Figure 4 is based on data from the EU KLEMS database ${ }^{14}$ and compares real wage growth in high-end manufacturing and lowend private services with economy-wide labour productivity in the $1974-1990$ period. $^{15}$ The graph shows that wages grew at approximately the same rate as productivity in both sectors in this period. However, as reported in Figure 5, the situation changed dramatically in 1991-2007: only high-end manufacturing was able to keep up with economy-wide productivity growth for some time, while service sector wages have been flat and even slightly declining in real terms.

Figure 5 supports the claim about dualization between manufacturing and services (Hassel, 2014; Thelen, 2014). However, the graph also suggests that even in the privileged manufacturing sector wages began to trail productivity from the early 2000s. Wages, especially in the service sector, have been affected by slack internal demand. Indeed, research has found a vicious circle between wage moderation and deficient internal demand. Wage moderation (together with welfare reforms) reduces the household disposable income and therefore depresses internal consumption, affecting particularly the demand for private services. In turn, stagnant demand has negative effects on employment and, ultimately, wages and

14 See http://www.euklems.net/ (March 2008 release).

15 High-end manufacturing includes the codes D21 through D37 according to the General Industrial Classification of Economic Activities (NACE): paper and pulp, petroleum products, chemicals, rubber and plastics, non-metallic mineral products, metal products, machinery, electrical and optical equipment, transportation equipment and manufacturing NEC; low-end services includes retail trade (NACE code G52) and hotels and restaurants (H). 


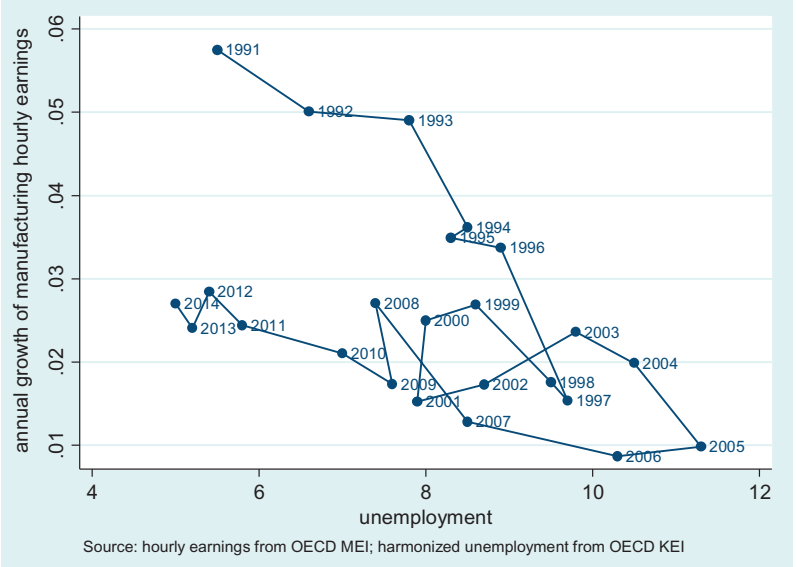

Figure 6. Relationship between nominal earnings and unemployment in Germany.

salaries (Freeman and Schettkat, 2002; Salverda and Schettkat, 2005; Herzog-Stein et al., 2013a).

An alternative interpretation of the wage trends is that they have little to do with developments in collective bargaining and simply reflect the dramatic increase in unemployment. Leaving aside the fact that this alternative interpretation would not account for the intersectoral pattern reported in Figure 5, Figure 6 reports a Phillips curve relationship between the annual growth of hourly earnings and unemployment in 1991-2014. Unsurprisingly, higher unemployment is associated with lower wage growth. However, the relationship seems to have shifted downwards in the post-crisis years, suggesting that wage moderation has continued even in the more recent years, despite much more favourable labour market conditions (see also Dustmann et al., 2014).

Overall, the wage trends reported above suggest that intersectoral redistribution and balanced wage growth were indeed features of the old German model, but not of the new one. Considering that the employment share of high-end manufacturing declined by approximately $30 \%$ in 35 years, while the share of low-end private services increased by $40 \%$ (based on EU KLEMS data), this situation implies that only a shrinking share of workers sees its real wages grow in proportion to productivity. As argued in Section 3, wage repression depresses domestic consumption and contributes to lock-in export-led growth.

Hassel (2014) has argued that stagnant wages in the service sector have been beneficial for the manufacturing sector in two ways: they have contributed to real exchange rate depreciation thus favouring export growth, and have boosted the real disposable income of workers in export industries. In other words, although export-led growth is based on wage repression, such repression has largely spared the manufacturing workers. Based on these distributional patterns, it may be argued that the export-led growth model is underwritten by a social coalition of export-oriented firms and core manufacturing workers, while service sector workers and atypical workers are the losers (Hassel, 2014; Thelen, 2014). However, the stability of this supporting coalition is threatened both by the more recent wage trends 


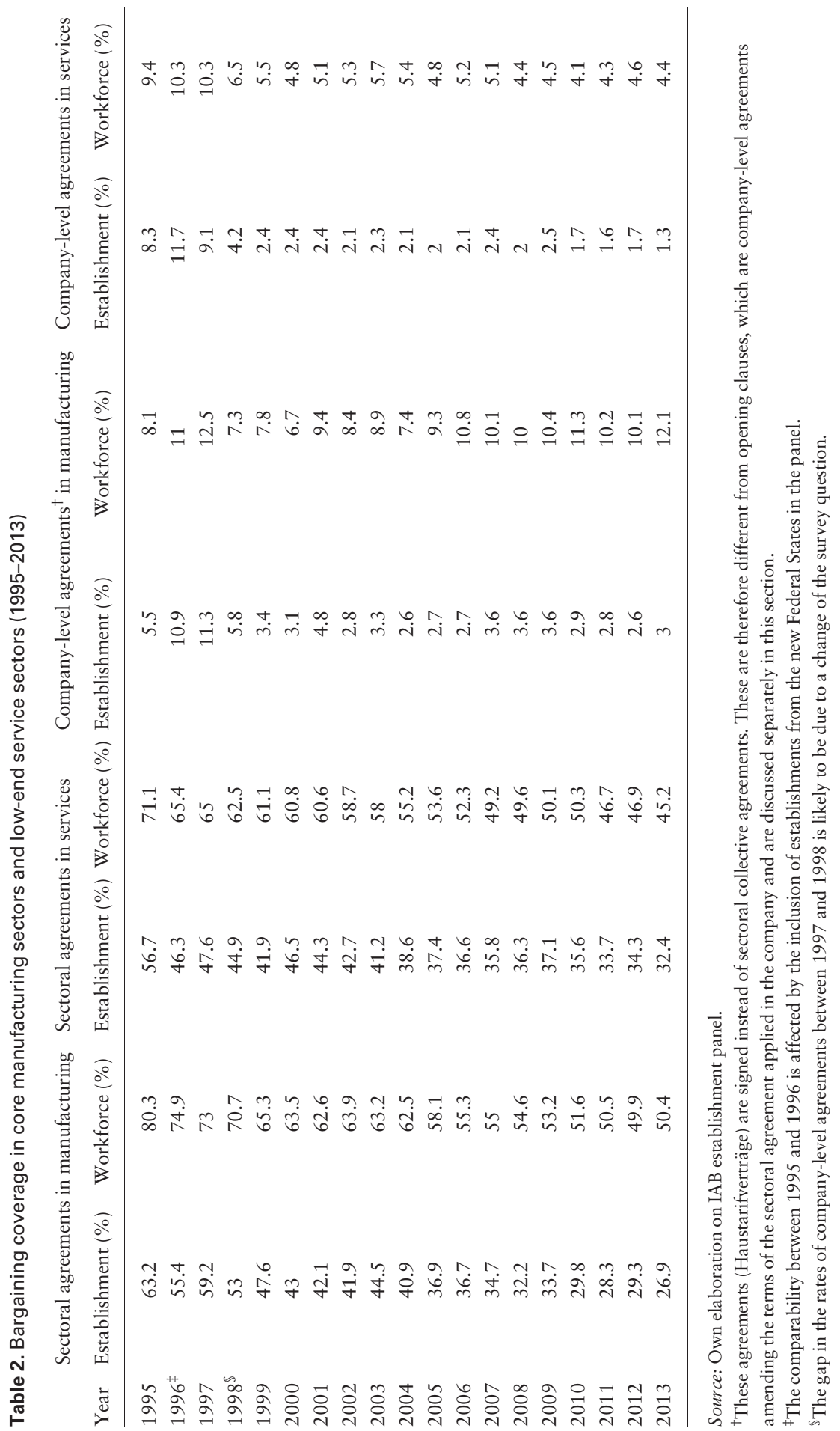


Table 3. Comparison of rates of permanent and contingent work in manufacturing and low-end services (1995-2013)

\begin{tabular}{|c|c|c|c|c|c|c|c|c|c|c|}
\hline \multirow[b]{2}{*}{ Year } & \multicolumn{2}{|c|}{ Permanent (\%) } & \multicolumn{2}{|c|}{ Part-time (\%) } & \multicolumn{2}{|c|}{ Marginal (\%) } & \multicolumn{2}{|c|}{ Fixed-term (\%) } & \multicolumn{2}{|c|}{ Agency (\%) } \\
\hline & Man & Ser & Man & Ser & Man & Ser & Man & Ser & Man & Ser \\
\hline 1995 & 87.5 & 63.94 & 6.02 & 23.83 & 2.66 & 7.40 & 3.83 & 4.84 & n.a. & n.a. \\
\hline $1996^{\dagger}$ & 87.44 & 62.15 & 5.92 & 23.80 & 2.58 & 7.59 & 4.07 & 6.47 & n.a. & n.a. \\
\hline 1997 & 87.97 & 59.78 & 5.61 & 27.99 & 1.89 & 6.21 & 4.52 & 6.02 & n.a. & n.a. \\
\hline 1998 & 87.46 & 58.39 & 5.68 & 28.09 & 1.80 & 7.87 & 5.06 & 5.65 & n.a. & n.a. \\
\hline $1999^{\ddagger}$ & 86.96 & 59.44 & 5.02 & 23.55 & 2.43 & 10.46 & 5.59 & 6.56 & n.a. & n.a. \\
\hline 2000 & 85.24 & 57.66 & 6.22 & 23.12 & 2.82 & 11.43 & 5.71 & 7.78 & n.a. & n.a. \\
\hline 2001 & 85.13 & 59.29 & 6.60 & 23.72 & 2.00 & 10.85 & 4.70 & 5.68 & 1.57 & 0.45 \\
\hline 2002 & 83.55 & 56.42 & 7.86 & 25.59 & 2.83 & 11.87 & 4.38 & 5.30 & 1.37 & 0.82 \\
\hline 2003 & 84.61 & 55.69 & 6.57 & 26.31 & 3.00 & 11.05 & 3.86 & 5.24 & 1.96 & 1.71 \\
\hline 2004 & 83.56 & 54.49 & 6.92 & 24.97 & 3.34 & 12.10 & 4.23 & 5.92 & 1.94 & 2.52 \\
\hline 2005 & 83.28 & 53.95 & 7.11 & 23.76 & 2.65 & 14.70 & 3.84 & 4.84 & 3.12 & 2.75 \\
\hline 2006 & 81.41 & 52.80 & 7.26 & 23.08 & 3.42 & 15.11 & 3.66 & 7.36 & 4.25 & 1.65 \\
\hline 2007 & 80.96 & 53.54 & 7.82 & 23.57 & 3.56 & 13.69 & 4.73 & 7.03 & 2.93 & 2.18 \\
\hline 2008 & 78.16 & 54.33 & 8.71 & 22.04 & 3.66 & 15.67 & $6.71^{\S}$ & 6.63 & 2.77 & 1.33 \\
\hline 2009 & 81.43 & 53.32 & 7.56 & 23.40 & 4.50 & 15.77 & 4.50 & 5.81 & 2.91 & 1.70 \\
\hline 2010 & 81.91 & 53.44 & 7.74 & 21.64 & 3.99 & 16.20 & 3.99 & 6.96 & 2.98 & 1.77 \\
\hline 2011 & 77.67 & 51.23 & 8.93 & 21.99 & 5.54 & 17.13 & 5.54 & 7.76 & 4.35 & 1.89 \\
\hline 2012 & 77.36 & 51.65 & 7.95 & 23.85 & 5.97 & 13.57 & 5.97 & 9.36 & 5.40 & 1.57 \\
\hline 2013 & 78.73 & 48.06 & 10.01 & 23.30 & 4.52 & $20.26^{\ddagger}$ & 4.52 & 7.34 & 3.28 & 1.04 \\
\hline
\end{tabular}

Source: Own elaboration on data from the German Socio-Economic Panel (SOEP).

${ }^{\dagger}$ The drop in the rate of self-reported marginal contracts (and increase in part-time job) is probably due to a change in the questionnaire.

${ }^{\ddagger}$ The increase of self-reported marginal contracts is probably due to changes in the regulation of mini jobs.

${ }^{\$}$ The increase of temporary contracts in 2008 might be due to new hirings on fixed-term contracts because of the economic uncertainty during the crisis.

suggesting that manufacturing wages, too, have begun to trail productivity increases on average, and by the increase of atypical work in the coordinated manufacturing core.

Data we collected from the German Socio-Economic Panel (1995-2013), reported in Table 3, suggest that the 'standard' employment relationship has been eroding not just in services but also in manufacturing even though the liberalization of the employment relationship still is (and has always been) greater in low-end services. Permanent contracts in manufacturing decreased from 87.5 in 1995 to $78 \%$ in 2013 while agency work increased from $1.57 \%$ in 2000 to $5.4 \%$ in 2012 and fixed-term contracts went from $3.83 \%$ to $5.97 \%$ in the same period. The situation improved a bit in 2013, with a marginal increase in the proportion of regular contracts in manufacturing and a decrease of atypical ones, but it is too early to speak of a reversal.

In addition to the increase of atypical contracts in manufacturing, there is circumstantial evidence suggesting that the boundaries between core workers in manufacturing and marginal workers in services have become increasingly blurred. In their study on the diffusion of atypical contracts across occupations in Germany, Marx (2011) and Eichhorst et al. (2015) 
have argued that labour market segmentation is more nuanced than suggested by the dualization scenario between stable manufacturing workers and precarious service employees because atypical contracts have been spreading also in occupations that used to be protected from job instability such as socio-cultural professionals and manufacturing workers. Furthermore, recent research found that employers have used agency contracts to replace permanent job positions and reduce labour costs since the Hartz reforms in 2004 (Promberger, 2012; Garz, 2013; Jahn and Weber, 2013), a line of argument that has been embraced by the Federal Government's 10th Report on Agency Work as well (cit. in IG Metall, 2007). Qualitative studies in automotive and machine tool building corroborate this claim, showing that core manufacturing workers and atypical workers often perform similar tasks, even in skilled positions (Holst et al., 2010; Benassi, 2016). This substitution process was found possible thanks to the limited firm-specific content of many job positions; at the same time, in those positions where more specific skills were required, managers were able to employ atypical workers for longer periods of time as these workers hoped to be hired on a permanent contract at the end of their 'temporary' assignment (Benassi, 2016).

As a result of these trends, the core manufacturing workforce and their representatives have started feeling that atypical work is a way to replace their jobs with more precarious and less costly ones (Eichhorst and Marx, 2011; Benassi and Dorigatti, 2015). While manufacturing unions have tried, on the one hand, to increase the costs of atypical work (especially agency work) through sectoral collective agreements (Benassi and Dorigatti, 2015), they have also been found to use wage moderation as an instrument for strengthening the competitiveness of core manufacturing workers against atypical workers (Eichhorst and Marx, 2011).

To sum up, while the evidence so far has supported the idea that export-led growth has affected the manufacturing and service sector in asymmetric ways, it has also shown that there hardly is an institutional equilibrium between the two labour market segments. The erosion of industrial relations institutions has advanced, slowly but steadily, also in the manufacturing sector, and wage moderation has affected the sector too in the last 15 years. Atypical contracts have increased in manufacturing as well, and evidence based on secondary literature suggests that they have started replacing permanent positions and undermining the bargaining power of core workers.

\section{Concluding remarks}

This article has sought to explain the institutional trajectory of German industrial relations in the last 20 years by focusing on the interaction between shifts in the growth model and meso- and micro-level restructuring and reform initiatives. The argument has proceeded in three steps. First, we have argued that Germany has moved from a growth model in which GDP growth was primarily pulled by household consumption to a model in which exports are the main growth engine. We have presented evidence suggesting that exports have become more price-sensitive than they had previously been in a large and important portion of the manufacturing sector. This points to the exhaustion of the DQP model of specialization in price-inelastic markets and suggests the emergence of a trade-off between exports and domestic household consumption: growth of the latter negatively affects the former through the REER. The implication is straightforward: to the extent that exports are the sole source of growth, growing the economy requires cutting domestic costs. 
Secondly, through an historical reconstruction, we have illustrated how the impetus to cut costs, particularly in export-oriented manufacturing firms, largely explains the trajectory of German industrial relations in the 1990s and 2000s. German firms have reacted to the need to regain competitiveness in various ways: they have reorganized industrial production in global supply chains and outsourced industrial services; they have reconfigured existing industrial relations institutions through, e.g. employers leaving employer organizations in order not to be forced to apply the negotiated terms, the widespread diffusion of derogatory plant-level bargaining, and the threat of outsourcing and offshoring. In the 1990s, there were also repeated attempts to address problems at the national level through Europeanstyle social pacts, but they failed. This pushed the government to engage in unilateral liberalization of the labour market, particularly of agency work and unemployment insurance. By increasing the fear of job losses, these legislative changes have further encouraged worker concessions (Eichhorst and Marx, 2011; Rebien and Kettner, 2011).

Third, we have provided an analysis of the current features of the German industrial relations system. Only half of the workforce in the manufacturing sector, and slightly more than one-fourth of establishments, are still covered by the sectoral collective agreement, and onefifth of the establishments applying the sectoral agreement make use of opening clauses. The severe erosion of the collective bargaining system has impaired the ability of pattern bargaining to transfer productivity increases into wage increases and to redistribute between sectors. In the 1974-1990 period, high-end manufacturing and low-end service wages grew more or less at the same rate, but in the 1991-2007 period only manufacturing wages were able to keep up with general productivity growth (with increasing difficulty from the early 2000s), while service wages were flat. While core manufacturing workers largely managed to shift wage repression onto the peripheral service workers, the notion that the former are protected from liberalization finds no support in our data. We have shown that atypical contracts have been increasing in core manufacturing sectors too, a trend that has been found to trigger downward competition between insiders and outsiders (Eichhorst and Marx, 2011). The argument developed here shares some features with the recent 'coordinationist' argument about dualization as it acknowledges that wage repression in the service sector has contributed to maintaining the costs of export production low (Herzog-Stein et al., 2013b). However, our argument emphasizes very different causal mechanisms and leads to different conclusions about the stability of the system. For example, while Thelen (2014)'s recent argument claims that liberalization happens by 'drift' as deindustrialization advances and the size of the manufacturing sector shrinks, our argument suggests that the impetus for change comes from the export sector itself, and specifically from the firms' cost-cutting imperative. As Germany becomes increasingly dependent on exports, the value for workers of holding a good job in the export sector increases relative to the alternatives, and so does their willingness to make concessions. This situation is likely to contribute to further collective bargaining erosion.

We would argue that the analysis of the 'co-evolution' between changing macroeconomic conditions and institutional dynamics has also allowed us to better specify the mechanisms of liberalization. Because of its exclusive focus on supply-side conditions, which it shares with the other camp, the 'liberalizer' literature (our own work included) has so far (in our view) failed to provide a fully convincing account of where the impetus to liberalize comes from, assuming that capital always liberalizes when it has its way. The analysis developed here suggests that the reasons are more specific. In the past, the growth model had allowed 
for a certain amount of 'slack'. With price-insensitive exports in a large chunk of manufacturing there was no trade-off between consumption and exports. In fact, institutional rigidities such as high wages and generous protections were even dynamically efficient to the extent that they encouraged industrial upgrading as argued by the DQP literature. But with exports becoming more price-sensitive, the slack turned into 'ballast' and firms started throwing it overboard (with a helping hand from government).

Our argument also implies that growth models are produced by a complex pattern of interaction between domestic and international factors and the conditions for their reproduction are not entirely at the disposal of national-level actors. Already more German cars are produced outside of Germany than inside (Deutsche Bank Research, 2011). Nobody can exclude that production phases that are currently carried out on German soil could one day be efficiently performed elsewhere at a lower cost. Equilibrium-based analyses ignore these developments at their peril. They suggest that still more ballast may have to be shed.

\section{Acknowledgements}

The authors thank participants in the seminar at the Max Planck Institute for the Study of Societies in Cologne, and in the CES and SASE conferences in June 2013 for comments on a previous version.

\section{References}

Baccaro, L. and Howell, C. (2011) 'A Common Neoliberal Trajectory: The Transformation of Industrial Relations in Advanced Capitalism', Politics \& Society, 39, 521-563.

Baccaro, L. and Pontusson, J. (2016) 'Rethinking Comparative Political Economy: The Growth Model Perspective', Politics \& Society, 44, 175-207.

Bayoumi, T., Harmsen, R. and Turunen, J. (2011) Euro Area Export Performance and Competitiveness, IMF Working Paper 11/140, Washington D.C., International Monetary Fund.

Benassi, C. (2016) 'Liberalization only at the margins? Analyzing the growth of temporary work in German core manufacturing sectors', British Journal of Industrial Relations, 54, 597-622.

Benassi, C. and Dorigatti, L. (2015) 'Straight to the Core: the IG Metall Campaign towards Agency Workers', British Journal of Industrial Relations, 53, 533-555.

Bhaduri, A. and Marglin, S. A. (1990) 'Unemployment and the Real Wage: The Economic Basis for Contesting Political Ideologies', Cambridge Journal of Economics, 14, 375-393.

Bispinck, R. (2012) 'Allgemeinverbindlicherklärung von Tarifverträgen - vom Niedergang zur Reform?’, WSI Mitteilungen, 7, 496-507.

Bispinck, R. and Schulten, T. (2000) 'Alliance for Jobs - is Germany Following the Path of “Competitive Corporatism"?'. In Fajertag, G. and Pochet P. (eds) Social Pacts in Europe: New Dynamics, Brussels, ETUI, pp. 187-218.

BMAS (2013) Verzeichnis der für allgemeinverbindlich erklärten Tarifverträge. Stand: 1. April 2013, Bonn, Bundesministerium für Arbeit und Soziales, Referat III a 8.

Bosch, G., Haipeter, T., Latniak, E. and Lehndorff, S. (2007) 'Demontage oder Revitalisierung?', KZfSS Kölner Zeitschrift für Soziologie und Sozialpsychologie, 59, 318-339.

Bosch, G. and Weinkopf, C. (2008) Low-Wage Work in Germany, New York, Russell Sage Foundation Publications.

Bowles, S. and Boyer, R. (1995) 'Wages, Aggregate Demand, and Employment in an Open Economy: An Empirical Investigation'. In Epstein, G. and Gintis, H. (eds) Macroeconomic 
Policy after the Conservative Era. Studies in Investment, Saving and Finance, Cambridge MA, Cambridge University Press, pp. 143-171.

Breuer, S. and Klose, J. (2014) 'Who Gains from Nominal Devaluation? An Empirical Assessment of Euro-Area Exports and Imports'. The World Economy, 38, 1966-1989.

Bundesagentur für Arbeit (2011) Zeitarbeit in Deutschland - Aktuelle Entwicklungen. Stand Juli 2011, Nürnberg, Bundesagentur für Arbeit.

Carlin, W. and Soskice, D. (2009) 'German Economic Performance: Disentangling the Role of Supply-Side Reforms, Macroeconomic Policy and Coordinated Economy Institutions', SocioEconomic Review, 7, 67-99.

Danninger, S. and Joutz, F. (2008) 'What Explains Germany's Rebounding Export Market Share?' CESifo Economic Studies, 54, 681-714.

Deutsche Bank Research (2011) Germany's Auto Industry: Driver and Beneficiary of Globalization, Frankfurt, Deutsche Bank.

Doellgast, V. and Greer, I. (2007) 'Vertical Disintegration and the Disorganization of German Industrial Relations', British Journal of Industrial Relations, 45, 55-76.

Doellgast, V. (2009) 'Still a Coordinated Model - Market Liberalization and the Transformation of Employment Relations in the German Telecommunications Industry', Industrial \& Labor Relations Review, 63, 3-23.

Dølvik, J. E. and Waddington, J. (2002) 'Private Sector Services: Challenges to European Trade Unions', Transfer: European Review of Labour and Research, 8, 356-376.

Dustmann, C., Fitzenberger, B., Schönberg, U. and Spitz-Oener, A. (2014) 'From Sick Man of Europe to Economic Superstar: Germany's Resurgent Economy', The Journal of Economic Perspectives, 28, 167-188.

Eichhorst, W. and Marx, P. (2011) 'Reforming German Labour Market Institutions: A Dual Path to Flexibility', Journal of European Social Policy, 21, 73-87.

Eichhorst, W., Marx, P. and Tobsch, V. (2015). 'Nonstandard Employment across Occupations in Germany: The Role of Replaceability and Labour Market Flexibility'. In Eichhorst, W. and Marx, P. (eds) Non-Standard Employment in Post-Industrial Labour Markets: An Occupational Perspective, Cheltenham, UK, Edgar Elgar, pp. 29-51.

Estevez-Abe, M., Iversen, T. and Soskice, D. (2001) 'Social Protection and the Formation of Skills: a Reinterpretation of the Welfare State'. In Hall, P. A. and Soskice, D. (eds) Varieties of Capitalism: The Institutional Foundations of Comparative Advantage, Oxford, Oxford University Press, pp.145-183.

European Commission (2014) 'Quarterly Report on the Euro Area', Economic and Financial Affairs, 13, 27-33.

Freeman, R. B. and Schettkat, R. (2002). Marketization of Production and the US-Europe Employment Gap, NBER Working Paper 8797, Cambridge, MA, National Bureau of Economic Research.

French, S. (2000) 'The Impact of Unification on German Industrial Relations', German Politics, 9, 195-216.

Garz, M. (2013) 'Employment and Wages in Germany since the 2004 Deregulation of the Temporary Agency Industry', International Labour Review, 152, 307-326.

Greer, I. (2008) 'Organized Industrial Relations in the Information Economy: The German Automotive Sector as a Test Case', New Technology, Work and Employment, 23, 181-196.

Haipeter, T. (2009) 'Kontrollierte Dezentralisierung? Abweichende Tarifvereinbarungen in der Metall-und Elektroindustrie', Industrielle Beziehungen/The German Journal of Industrial Relations, 16, 232-253.

Hall, P. A. (2007) 'The Evolution of Varieties of Capitalism'. In Hancké, B., Rhodes, M. and Thatcher, M. (eds) Beyond Varieties of Capitalism: Conflict, Contradiction, and 
Complementarities in the European Economy, Oxford/New York, Oxford University Press, pp. 39-87.

Hall, P. A. and Soskice, D. (eds) (2001a) Varieties of Capitalism: The Institutional Foundations of Comparative Advantage, Oxford/New York, Oxford University Press.

Hall, P. A. and Soskice, D. (2001b) 'An Introduction to Varieties of Capitalism'. In Hall, P. A. and Soskice, D. (eds.) Varieties of Capitalism: The Institutional Foundations of Comparative Advantage, New York, Oxford University Press, pp.1-68.

Hartwig, J. (2014) 'Testing the Bhaduri-Marglin Model with OECD Panel Data', International Review of Applied Economics, 28, 419-435.

Hassel, A. (1999) 'The Erosion of the German System of Industrial Relations.' British Journal of Industrial Relations, 37, 483-505.

Hassel, A. (2014) 'The Paradox of Liberalization - Understanding Dualism and the Recovery of the German Political Economy', British Journal of Industrial Relations, 52, 57-81.

Hassel, A. and Rehder, B. (2001) Institutional Change in the German Wage Bargaining System: The Role of Big Companies, Cologne, Max-Planck Institute for the Study of Societies.

Hassel, A. and Streeck, W. (2004). 'The Crumbling Pillars of Social Partnership'. In Streeck, W. and Kitschelt, H. (eds) Germany: Beyond the Stable State, London, Frank Cass, pp. 101-124.

Hassel, A. and Schiller, C. (2010) Der Fall Hartz IV: wie es zur Agenda 2010 kam und wie es weitergeht, Frankfurt am Main, Campus.

Hassel, A. and Schulten, T. (1998), 'Globalization and the Future of Central Collective Bargaining: The Example of the German Metal Industry', Economy and Society, 27, 486-522.

Helfen, M. (2011) 'Tarifpolitisch Parallelwelten', Die Mitbestimmung, 7 + 8, 20-33.

Herrigel, G. (1997) 'The Limits of German Manufacturing Flexibility'. In Turner, L. (ed.) Negotiating the New Germany. Can Social Partnership Survive, Ithaca/London, Cornell University Press, pp.177-205

Herrigel, G. (2015) 'Globalization and the German Industrial Production Model', Journal for Labour Market Research, 48, 133-149.

Herrigel, G., Wittke, V. and Voskamp, U. (2013). 'The Process of Chinese Manufacturing Upgrading: Transitioning from Unilateral to Recursive Mutual Learning Relations', Global Strategy Journal, 3, 109-125.

Herzog-Stein, A., Joebges, H., Stein, U. and Zwiener, R. (2013a) Labour Cost Trends and International Competitiveness in Europe, IMK Report 88e, Düsseldorf, Institut für Makroökonomie und Konjunkturforschung.

Herzog-Stein, A., Lindner, F.and Zwiener, R. (2013b). Is the Supply Side All That Counts?, IMK Report 87e, Düsseldorf, Institut für Makroökonomie und Konjunkturforschung.

Holst, H. (2014) “"Commodifying Institutions”: Vertical Disintegration and Institutional Change in German Labour Relations', Work, Employment \& Society, 28, 3-20.

Holst, H., Nachtwey, O. and Dörre, O. (2010) 'The Strategic Use of Temporary Agency Work Functional Change of a Non-standard Form of Employment', International Journal of Action Research, 6, 108-138.

Höpner, M. and Jackson, G. (2002) 'Das deutsche System der Corporate Governance zwischen Persistenz und Konvergenz', KZfSS Kölner Zeitschrift für Soziologie und Sozialpsychologie, 54, 362-368.

Höpner, M., Petring, A., Seikel, D. and Werner, B. (2011) 'Liberalisierungspolitik: Eine Bestandsaufnahme des Rückbaus wirtschafts-und sozialpolitischer Interventionen in entwickelten Industrieländern (Abhandlungen)', Kölner Zeitschrift für Soziologie und Sozialpsychologie, $63,1-32$.

IG Metall (2007) Sozialreport Zeitarbeit, Berlin, IG Metall Bezirksleitung Berlin-BrandenburgSachsen. 
Jacobi, L. and Kluve, J. (2006) Before and after the Hartz reforms: The performance of active labour market policy in Germany, Discussion Paper 2100, Bonn, Institute for the Study of Labor.

Jahn, E. and Weber, E. (2013) Zeitarbeit: Zusätzliche Jobs, aber auch Verdrängung, IAB Kurzbericht 2/2013, Nürnberg, Institut für Arbeitsmarkt und Berufsforschung.

Jürgens, U. (1997) 'Germany: Implementing Lean Production'. In Koch, T. A., Lannsbury, R. D. and MacDuffie, J. P. (eds) After Lean Production: Evolving Employment Practices in the World Auto Industry, Ithaca, Cornell University Press, pp.109-116.

Jürgens, U. (2004) 'An Elusive Model-Diversified Quality Production and the Transformation of the German Automobile Industry', Competition and Change, 8, 411-423.

Jürgens, U. and Krzywdzinski, M. (2006) Globalisierungsdruck und Beschäftigungssicherung Standortsicherungsvereinbarungen in der deutschen Automobilindustrie zwischen 1993 und 2006, WZB Discussion Paper SP III, Berlin, Social Science Research Centre.

Kinderman, D. (2005) 'Pressure from Without, Subversion from Within: The Two-Pronged German Employer Offensive', Comparative European Politics, 3, 432-463.

Kinkel, S. and Lay, G. (2003) Fertigungstiefe - Ballast oder Kapital? Stand und Effekte von Outund Insourcing im Verarbeitenden Gewerbe Deutschlands, Mitteilungen aus der Produktionsinnovationserhebung 30 (August 2003), Karlsruhe, Fraunhofer-Institut für Systemtechnik und Innovationsforschung.

Kinkel, S. and Maloca, S. (2009) 'Drivers and Antecedents of Manufacturing Offshoring and Backshoring - A German Perspective', Journal of Purchasing and Supply Management, 15, 154-165.

Klär, E. and Slacalek J. (2006) 'Entwicklung der Sparquote in Deutschland: Hindernis für die Erholung der Konsumnachfrage', DIW Wochenbericht, 73, 537-543.

Lindlar, L. and Scheremet, W. (1998) Germany's Slump Explaining the Unemployment Crisis of the 1990s, Diskussionspapier 169/1998, Berlin, Deutsches Institut für Wirtschaftsforschung.

Ludwig, U. and Brautzsch, H.U. (2008) 'Has the International Fragmentation of German Exports Passed Its Peak?', Intereconomics, 43, 176-180.

Marx, P. (2011) The Unequal Incidence of Non-Standard Employment Across Occupational Groups: An Empirical Analysis of Post-Industrial Labour Markets in Germany and Europe, IZA Discussion Paper No. 5521, Bonn, Institute for the Study of Labor.

Machin, S. (1997). 'The Decline of Labour Market Institutions and the Rise in Wage Inequality in Britain', European Economic Review, 41, 647-657.

Menz, G. (2005) 'Old Bottles-New Wine: The New Dynamics of Industrial Relations', German Politics, 14, 196-207.

Müller-Jentsch, W. (1995) 'Auf dem Prüfstand: Das deutsche Modell der industriellen Beziehungen', Industrielle Beziehungen, 2, 11-24.

Niedenhoff, H.U. (1981) Die Betriebsräte von 1981 bis 1984: eine Analyse der Betriebsratswablen, Cologne, Deutsches Institutsverlag.

Onaran, Ö. and Galanis, G. (2012) Is aggregate demand wage-led or profit-led? National and global effects, ILO Conditions of Work and Employment Series No. 40, Geneva, International Labor Office.

Onaran, Ö. and Galanis, G. (2014) 'Income Distribution and Growth: A Global Model', Environment and Planning A, 46: 2489-2513.

Palier, B. and Thelen, K. (2010) 'Institutionalizing Dualism: Complementarities and Change in France and Germany', Politics \& Society, 38, 119-148.

Promberger, M. (2012) Topographie der Leiharbeit. Flexibilität und Prekarität einer atypischen Beschäftigungsform, Berlin, Hans Böckler Stiftung.

Raess, D. (2006) 'Globalization and Why the 'Time Is Ripe' for the Transformation of German Industrial Relations', Review of International Political Economy, 13, 449-79. 
Rebien, M. and Kettner, A. (2011) 'Die Konzessionsbereitschaft von Bewerbern und Beschäftigten nach den Hartz-Reformen', WSI Mitteilungen, 5, 218-225.

Rehder, B. (2003) Betriebliche Bündnisse für Arbeit in Deutschland: Mitbestimmung und Flächentarif im Wandel, Frankfurt am Main, Campus.

Rueda, D. and Pontusson, J. (2000) 'Wage Inequality and Varieties of Capitalism', World Politics, 52(April): 350-383.

Salverda, W. and Schettkat R. (2005). Demand patterns and employment growth: consumption and services in France, Germany, the Netherlands, Spain, the United Kingdom and the United States. DEMPATEM report: Improving the Socio-Economic Knowledge Base-Concluding Summary, Working Paper 13, Amsterdam, Amsterdam Institute for Advanced Labor Studies.

Scharpf, F.W. (1997) Employment and the Welfare State: A Continental Dilemma, MPIfG Working Paper 97/7, Cologne, Max-Planck Institute for the Study of Societies.

Schulten, T. (2001) Solidarische Lohnpolitik in Europa. Ansätze und Perspektiven einer Europäisierung gewerkschaftlicher Lohnpolitik, WSI Diskussionspapier Nr. 92, Düsseldorf, Wirtschafts- und Sozialwissenschaftliches Institut.

Seifert, H. and Massa-Wirth, H. (2005). 'Pacts for Employment and Competitiveness in Germany', Industrial Relations Journal, 36, 217-240.

Silvia, S. J. and Schroeder, W. (2007) 'Why Are German Employers Associations Declining? Arguments and Evidence', Comparative Political Studies, 40, 1433-1459.

Sinn, H. W. (2006) 'The Pathological Export Boom and the Bazaar Effect: How to Solve the German Puzzle', The World Economy, 29, 1157-1175.

Soskice, D. (1999) 'Divergent Production Regimes: Coordinated and Uncoordinated Market Economies in the 1980s and 1990s'. In Kitschelt, H., Lange, P., Marks, G. and Stephens, J. D. (eds) Continuity and Change in Contermporary Capitalism, Cambridge/New York, Cambridge University Press, pp. 101-134.

Stahn, K. (2006) Has the Impact of Key Determinants of German Exports Changed? Results from Estimations of Germany's Intra Euro-Area and Extra Euro-Area Exports, DB Discussion Paper Series 1: Economic Studies 07/2006, Frankfurt am Main, Deutsche Bank.

Stockhammer, E. (2015) 'Rising Inequality as a Cause of the Present Crisis', Cambridge Journal of Economics, 39: 935-958.

Stockhammer, E., Onaran, Ö. and Ederer, S. (2009) 'Functional Income Distribution and Aggregate Demand in the Euro Area', Cambridge Journal of Economics, 33, 139-159.

Stockhammer, E., Hein, E. and Grafl, L. (2011) 'Globalization and the Effects of Changes in Functional Income Distribution on Aggregate Demand in Germany', International Review of Applied Economics, 25:1-23.

Storm, S. and Naastepad, C. W. M. (2012) Macroeconomics Beyond the NAIRU, Cambridge, MA, Harvard University Press.

Storm, S. and Naastepad, C. W. M. (2015) 'Crisis and Recovery in the German Economy: The Real Lessons', Structural Change and Economic Dynamics, 32, 11-24.

Streeck, W. (1991) 'On Institutional Conditions of Diversified Quality Production'. In Matzner, E. and Streeck, W. (eds) Beyond Keynesianism: The Socio-Economic of Production and Full Employment, Aldershot/Brookfield, Edwar Elgar, pp. 21-61.

Streeck, W. (1997a) 'Beneficial Constraints: On the Economic Limits of Rational Voluntarism'. In Boyer, R. and Hollingsworth, R. J. (eds) Contemporary Capitalism: The Embeddedness of Institutions, Cambridge/New York, Cambridge University Press, pp.197-219.

Streeck, W. (1997b) ‘German Capitalism: Does It Exist? Can It Survive?’, New Political Economy, 2, 237-256.

Streeck, W. (2009) Re-Forming Capitalism: Institutional Change in the German Political Economy, Oxford, Oxford University Press. 
Streeck, W. and Thelen, K. (2005) Beyond Continuity: Institutional Change in Advanced Political Economies, Oxford/New York, Oxford University Press.

Thelen, K. (1991) Union of Parts: Labour Politics in Postwar Germany, Ithaca, NY, Cornell University Press.

Thelen, K. (2001) 'Varieties of Labour Politics in the Developed Democracies'. In Hall, P. A. and Soskice, D. (eds) Varieties of Capitalism: The Institutional Foundations of Comparative Advantage, Oxford, Oxford University Press, pp. 71-103.

Thelen, K. (2014) Varieties of Liberalization and the New Politics of Social Solidarity, Cambridge, MA, Cambridge University Press.

Thelen, K. and van Wijnbergen, C. (2003) 'The Paradox of Globalization: Labour Relations in Germany and Beyond', Comparative Political Studies, 36, 859-880.

Thorbecke, W. and Kato, A. (2012) The Effect of Exchange Rate Changes on Germany's Exports, RIETI Discussion Paper Series 12-E-081, Tokyo, Research Institute of Economy, Trade and Industry.

Turner, L. (1998) Fighting For Partnership: Labour and Politics in Unified Germany, Cambridge MA, Cambridge University Press.

Upchurch, M. (2000) 'The Crisis of Labour Relations in Germany', Capital \& Class, 24, 65-93.

Wallerstein, M. (1999) 'Wage-Setting Institutions and Pay Inequality in Advanced Industrial Societies', American Journal of Political Science, 43:649-680. 
Appendix A: Empirical studies on the price elasticity of German exports

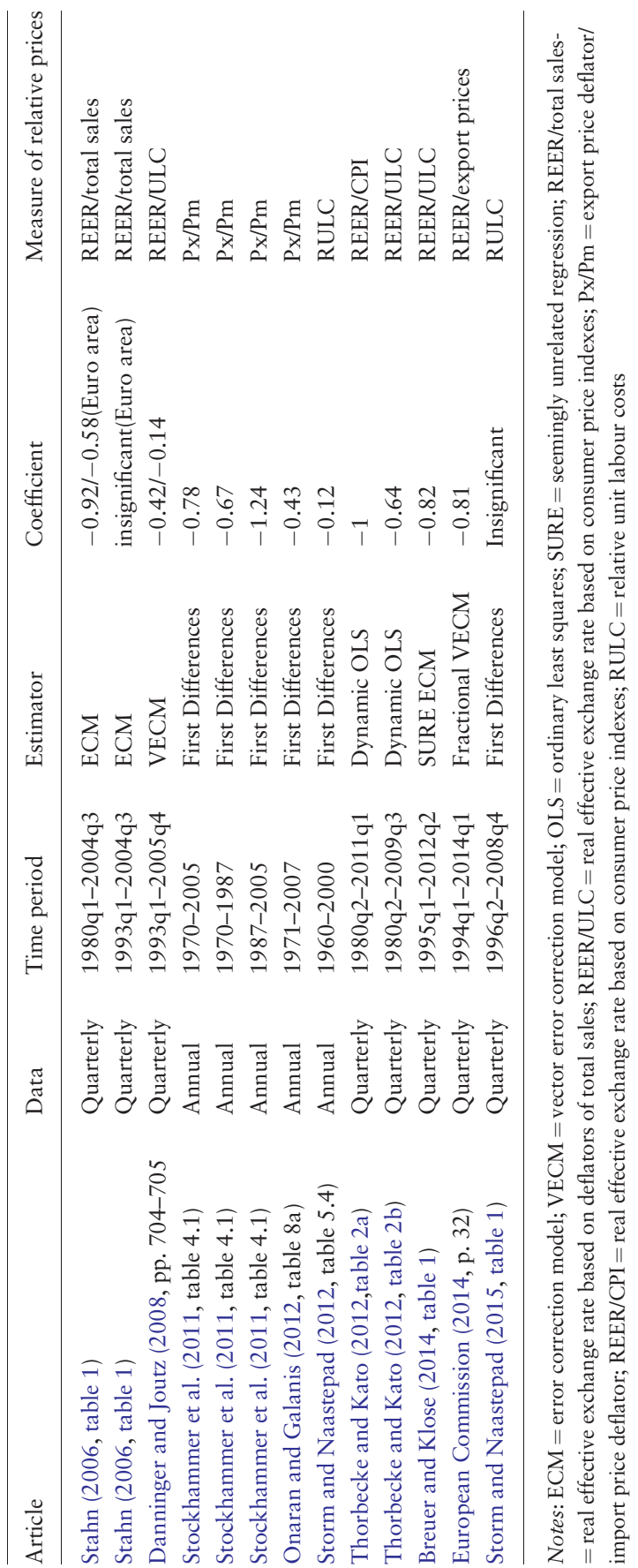

